Article

\title{
Phylogeny and Density Dynamics of Wolbachia Infection of the Health Pest Paederus fuscipes Curtis (Coleoptera: Staphylinidae)
}

\author{
Chen Ge ${ }^{1,+}{ }^{\dagger}$ Jiayao Hu ${ }^{1,+}$, Zimiao Zhao $^{1,+}{ }^{\dagger}$ Ary A. Hoffmann ${ }^{2} \oplus$, Shuojia Ma ${ }^{1}$, Li Shen ${ }^{1}$, \\ Jie Fang ${ }^{1}$, Jianqing $\mathrm{Zhu}^{3}$, Weidong $\mathrm{Yu}^{1}$ and Weibin Jiang ${ }^{1, *(D)}$ \\ 1 Laboratory of Environmental Entomology, College of Life Sciences, Shanghai Normal University, \\ Xuhui, Shanghai 200234, China; gretchen9505@163.com (C.G.); hujiayao@shnu.edu.cn (J.H.); \\ zhaozimiao818926@163.com (Z.Z.); mashuojia@126.com (S.M.); shenlismile@163.com (L.S.); \\ fangjie2019@163.com (J.F.); ywd@shnu.edu.cn (W.Y.) \\ 2 School of BioSciences, The University of Melbourne, Bio21 Institute, Parkville, VIC 3052, Australia; \\ Ary@unimelb.edu.au \\ 3 Shanghai Zoological Park, Changning, Shanghai 200335, China; zzzjjq@gmail.com \\ * Correspondence: jiangwb@shnu.edu.cn \\ + These authors contributed equally to this work.
}

Received: 30 July 2020; Accepted: 8 September 2020; Published: 11 September 2020

Simple Summary: Wolbachia pipientis is a maternally inherited endosymbiont of arthropods and filarial nematodes, and was reported to occur in Paederus fuscipes, a beetle that causes dermatitis linearis and conjunctivitis in humans when they come in contact with skin. In this study, we report the phylogenetic position and density dynamics of Wolbachia in P. fuscipes. The phylogeny of Wolbachia, based on an analysis of MLST genotyping, showed that Wolbachia from P. fuscipes belongs to supergroup B. Quantitative PCR indicated that the infection density in adults was higher than in any other life stage (egg, larva or pupa), and that reproductive tissue in adults had the highest infection densities, with similar densities in the sexes. These findings provide a starting point for understanding Wolbachia infection dynamics in P. fuscipes, and interactions with other components of the microbiota.

Abstract: The maternally inherited obligate intracellular bacteria Wolbachia infects the reproductive
tissues of a wide range of arthropods and affects host reproduction. Wolbachia is a credible biocontrol
agent for reducing the impact of diseases associated with arthropod vectors. Paederus fuscipes is a small
staphylinid beetle that causes dermatitis linearis and conjunctivitis in humans when they come into
contact with skin. Wolbachia occur in this beetle, but their relatedness to other Wolbachia, their infection
dynamics, and their potential host effects remain unknown. In this study, we report the phylogenetic
position and density dynamics of Wolbachia in P. fuscipes. The phylogeny of Wolbachia based on
an analysis of MLST genotyping showed that the bacteria from P. fuscipes belong to supergroup B.
Quantitative PCR indicated that the infection density in adults was higher than in any other life
stage (egg, larva or pupa), and that reproductive tissue in adults had the highest infection densities,
with similar densities in the sexes. These findings provide a starting point for understanding the
Wolbachia infection dynamics in P. fuscipes, and interactions with other components of the microbiota.

Keywords: Paederus fuscipes; Wolbachia infection; phylogeny; density dynamics 


\section{Introduction}

Wolbachia pipientis is the most widespread endosymbiotic bacterium of insects and other arthropods, infecting perhaps two-thirds of present-day insect species, as well as about $40 \%$ of terrestrial arthropod species [1]. The transmission of Wolbachia is predominantly vertical and secondarily horizontal [2]. It can induce a number of reproductive manipulations in its host, including cytoplasmic incompatibility [3], thelytokous parthenogenesis [4], feminization of genetic males [5] and male killing [6]. Wolbachia may generate positive fitness effects on numerous hosts, such as filarial nematodes, fruit flies, bedbugs and wasps [7-10], and decrease host transmission of dengue [11], malaria [12], West Nile virus [13] and other pathogens [14]. It is considered as a novel method for controlling mosquito- and vector-borne human diseases [15]. The vector control approaches include population suppression [16-18] and population replacement strategies [19]. The population suppression approaches involve rearing and releasing large numbers of male mosquitoes that cannot produce viable offspring when they mate with wild females. By contrast, population replacement approaches involve the release of both male and female mosquitoes that carry a heritable factor that reduces or blocks their ability to transmit viruses [15].

Wolbachia infections have been reported in various Coleoptera families, such as Buprestidae, Chrysomelidae, Curculionidae, Dytiscidae, Gyrinidae, Haliplidae, Hydraenidae, Hydrophilidae, Noteridae, Staphilinidae and Tenebrionidae, but usually only with a limited coverage of species [20-26]. Paederus fuscipes Curtis is a widespread beetle, with a distribution from the British Isles in the east, across Central Asia to Japan, and southeast to Australia. Although P. fuscipes preys on several agricultural pests and represents an important beneficial insect [27], it can also adversely affect human health, because its vesicant hemolymph can cause dermatitis linearis and conjunctivitis if it comes into contact with human skin [28-30]. P. fuscipes neither bite nor sting, but can cause dermatitis linearis and conjunctivitis by accidental brushing or crushing of the insects over an exposed area of the human skin. The symptoms are due to a toxic substance named pederin released from their hemolymph [31]. P. fuscipes was originally examined with respect to Wolbachia infection by Yun et al. [26], and its infection status was recently confirmed by Maleki-Ravasan et al. [24]. Yun et al. [26] found the indirect horizontal transmission of Wolbachia between rove beetles and their predator spiders, while Maleki-Ravasan et al. [24] provided an estimate of Wolbachia prevalence $(76 \%, 95 / 125)$ in P. fuscipes in Iran. However, little is known about other aspects of this infection, including its tissue distribution patterns and density dynamics in $P$. fuscipes.

The tissue distribution of Wolbachia in its hosts is often uneven [32]. Based on initial studies in mosquitoes and Drosophila, high densities of Wolbachia were found in reproductive tissues $[3,33,34]$, which was thought to be connected to transovarial transmission and the ability of Wolbachia to influence host reproduction [35]. A wider somatic tissue distribution of Wolbachia has been reported in other arthropods, such as isopods [36], triatomine bugs [37] and bean beetles [38]. Wolbachia density also varies between life stages, and can shift in density towards specific organs during development [39].

In this study, we characterized the Wolbachia in P. fuscipes by MLST genotyping. Furthermore, we measured Wolbachia density across all the developmental stages, body parts and tissues of P. fuscipes with qPCR. The Wolbachia spatiotemporal infection density in beetles may help to indicate the likely effects of Wolbachia on this host.

\section{Materials and Methods}

\subsection{Samples and DNA Extraction}

A laboratory stock of $P$. fuscipes was established from 33 adult beetles (18 females and 15 males) collected in Nanyang, Henan province, China, in May 2019. They were fed separately under greenhouse conditions at $25^{\circ} \mathrm{C}, 60 \%$ relative humidity and a photoperiod of $16 \mathrm{~h}$ of light and $8 \mathrm{~h}$ of darkness. To establish isofemale lines, beetle pairs were kept in a fixed order in perforated plastic boxes, as described by Kellner and Dettner [40], with some leaves for shelter, and a small dish containing moistened cotton in which to lay the eggs. The females were fed with pork liver powder and honey 
(50 $\mu \mathrm{g}$ for one beetle per day) and were allowed to lay eggs seven days later. The eggs were isolated for hatching, and the isofemale line was established using resulting sibling larvae.

DNA was isolated from different developmental stages of the F1 generation (egg, larva, pupa and adult) and parental samples. Nine rove beetles were tested per developmental stage, except for the eggs, which were tested in nine groups of three eggs ( $n=27$ in total). The tissues (gut and reproductive tissue) and body parts (head, thorax, and abdomen without the gut and gonads) were dissected from other adult beetles ( 9 males and 9 females). Each tissue sample was dissected from a beetle. The method of dissection was carried out following Kador et al. [41]. The DNA was isolated from the dissected body parts and tissues using a QIAamp DNA Mini kit (Qiagen, Hilden, Germany) following the manufacturer's instructions [42].

\subsection{Wolbachia Screening and Multilocus Sequence Typing}

To screen for the presence of Wolbachia, a region of $870 \mathrm{bp}$ in length was amplified from all the samples using general Wolbachia primers for 16S rRNA [43] (Table 1). The PCR reactions followed the published protocols [44]. The characterization of Wolbachia strains was performed by sequencing multiple loci recommended by the Wolbachia MLST database (http://pubmlst.org/Wolbachia) [45,46] (Table 1). The MLST typing included sequencing fragments from five Wolbachia genes: gat $B, \operatorname{cox} A$, hcpA, ftsZ and fbpA.

The MLST data were aligned with a homologous sequence of a wide range of arthropods retrieved from the Wolbachia MLST database (http://pubmlst.org/Wolbachia) as well as from the NCBI database (Supplementary Materials Table S1). These sequences were aligned with manual correction using Bioedit v. 7.0 [47]. The best-fit partitioning scheme and corresponding nucleotide substitution models for the concatenated matrix were selected by PartitionFinder v2.1.1 [48] using the Bayesian Information Criterion (BIC). The GTR $+R$ model is the best-fit substitution model for five partitions. The concatenated supermatrix was analyzed with maximum likelihood (ML) inference using IQtree 1.4.2 [49]. IQtree is an efficient software for phylogenomic inference. A combination of hill-climbing approaches and astochastic perturbation method can be time-efficiently implemented. To assess nodal support, we performed 1000 ultrafast bootstrap replicates and an SH-aLRT test with 1000 replicates. The UFBoot is largely unbiased compared to standard or alternative bootstrap strategies, and SH-aLRT is conservative [50-52]. Only nodes with support values of UFBoot $\geq 80$ and $\mathrm{SH}-\mathrm{aLRT} \geq 75$ were considered robust. 
Table 1. Primer sequences and amplicon lengths of PCR products of target genes.

\begin{tabular}{|c|c|c|c|c|c|}
\hline Gene/Region & Primers & Sequence $\left(5^{\prime}-3^{\prime}\right)$ & Amplicon Length & Annealing Temperature & Reference \\
\hline $16 \mathrm{~S}$ rRNA & $\begin{array}{l}16 S \_F \\
16 S R\end{array}$ & $\begin{array}{c}\text { TTGTAGCCTGCTATGGTATAACT } \\
\text { GAATAGGTATGATTTTCATGT }\end{array}$ & $870 \mathrm{bp}$ & $55^{\circ} \mathrm{C}$ & [43] \\
\hline gatB & $\begin{array}{l}\text { gatB_F1 } \\
\text { gatB_R1 }\end{array}$ & $\begin{array}{l}\text { GAKTTAAAYCGYGCAGGBGTT } \\
\text { TGGYAAYTCRGGYAAAGATGA }\end{array}$ & $471 \mathrm{bp}$ & $54{ }^{\circ} \mathrm{C}$ & [46] \\
\hline $\operatorname{cox} A$ & $\begin{array}{l}\text { COxA_F1 } \\
\text { CoxA_R1 }\end{array}$ & $\begin{array}{l}\text { TTGGRGCRATYAACTTTATAG } \\
\text { TCTAAAGACTTTKACRCCAGT }\end{array}$ & $487 \mathrm{bp}$ & $54^{\circ} \mathrm{C}$ & [46] \\
\hline$h c p A$ & $\begin{array}{l}\text { CoxA_F1 } \\
\text { CoxA_R1 }\end{array}$ & $\begin{array}{l}\text { GAAATARCAGTTGCTGCAAA } \\
\text { GAAAGTYRAGCAAGYTCTG }\end{array}$ & $515 \mathrm{bp}$ & $54^{\circ} \mathrm{C}$ & [46] \\
\hline ftsZ & $\begin{array}{l}\mathrm{ftsZ} F \text { F1 } \\
\mathrm{ftsZ \_ R1}\end{array}$ & $\begin{array}{c}\text { ATYATGGARCATATAAARGATAGTCR } \\
\text { AGYAATGGATTRGATAT }\end{array}$ & $524 \mathrm{bp}$ & $54{ }^{\circ} \mathrm{C}$ & [46] \\
\hline$f b p A$ & $\begin{array}{l}\text { fbpA_F1 } \\
\text { fbpA_R1 }\end{array}$ & $\begin{array}{c}\text { GCTGCTCCRCTTGGYWTGAT } \\
\text { CCRCCAGARAAAAYYACTATTC }\end{array}$ & $509 \mathrm{bp}$ & $59^{\circ} \mathrm{C}$ & [46] \\
\hline$w s p$ & $\begin{array}{l}\text { wsp1_F1 } \\
\text { wsp1_R1 }\end{array}$ & $\begin{array}{l}\text { TGGTATTGGTGTTGGTGCAG } \\
\text { AACCGAAATAACGAGCTCCA }\end{array}$ & $158 \mathrm{bp}$ & $50^{\circ} \mathrm{C}$ & [53] \\
\hline RPS3 & $\begin{array}{l}\text { RPS3_F } \\
\text { RPS3_R }\end{array}$ & $\begin{array}{l}\text { CCCAGATAATCATTATCG } \\
\text { CAGATTGAATGTGTGACAC }\end{array}$ & $191 b p$ & $50{ }^{\circ} \mathrm{C}$ & [54] \\
\hline
\end{tabular}




\section{3. $q P C R$ and Statistical Analyses}

To measure the infection dynamics of Wolbachia across all tested developmental stages, body parts and tissues of $P$. fuscipes, qPCR was performed in triplicate for each sample using Platinum SYBR Green (Invitrogen) referring to the manufacturer's protocol. qPCR reactions were performed in a total volume of $20 \mu \mathrm{L}$, comprising $10 \mu \mathrm{L}$ of $2 X$ Platinum SYBR Green, $0.4 \mu \mathrm{L}(5 \mu \mathrm{M})$ of each primer and $1 \mu \mathrm{L}$ (final $5 \mathrm{ng}$ ) template DNA. Following Ali et al. [53], the relative Wolbachia density was calculated as the ratio of Cq values between the Wolbachia surface protein gene (wsp) and the host's ribosomal protein S3 gene (RPS3), which is synonymous with the number of Wolbachia per host cells, because both genes occur as a single copy per haploid genome. The short fragment length (158 bp) of the Wolbachia targeted primer pair (wsp1-F1-wsp1-R1) was used and normalized with a 191bp fragment length of the reference gene (RPS3-F, RPS3-R; Table 1) [53,54]. Relative expression levels were calculated using the $2^{-\Delta \Delta \mathrm{Ct}}$ method [55]. The temperature profile of the qPCR was $94{ }^{\circ} \mathrm{C}$ for $4 \mathrm{~min}, 40$ cycles of $95{ }^{\circ} \mathrm{C}$ for $30 \mathrm{~s}, 50^{\circ} \mathrm{C}$ for $30 \mathrm{~s}$, and $72{ }^{\circ} \mathrm{C}$ for $45 \mathrm{~s}$ with fluorescence acquisition of $72{ }^{\circ} \mathrm{C}$ at the end of each cycle, then a melting curve analysis after the final cycle. Assays were conducted as three technical replicates.

We checked for the normality and homoscedasticity of the data prior to using parametric statistical tests. We compared Wolbachia infection densities among the different developmental stages, body parts and tissues of $P$. fuscipes by ANOVA followed by a multiple comparison test (Tukey's posthoc test). We used $t$-tests to compare Wolbachia densities between males and females. All analyses were conducted using SPSS statistics version 21.0 for Windows (SPSS Inc, Chicago, IL, USA).

\section{Results}

All rove beetles examined by diagnostic PCR for 16SrRNA were Wolbachia-infected. All individuals appeared to have a single infection based on unambiguous electropherograms. The sequence typing of these individuals produced new alleles for the $h c p A$ and $\operatorname{cox} A$ loci, with $f t s Z, f b p A$ and gatB matching existing alleles in the database. The strain identified by the Wolbachia MLST database has the designation ST-540. The phylogenetic trees for concatenated alignment were constructed and showed that ST-540 belonged to supergroup B (Figure 1). The most closely related strain was a male-killing Wolbachia (ST-3) in the butterfly Acraea encedon [56].

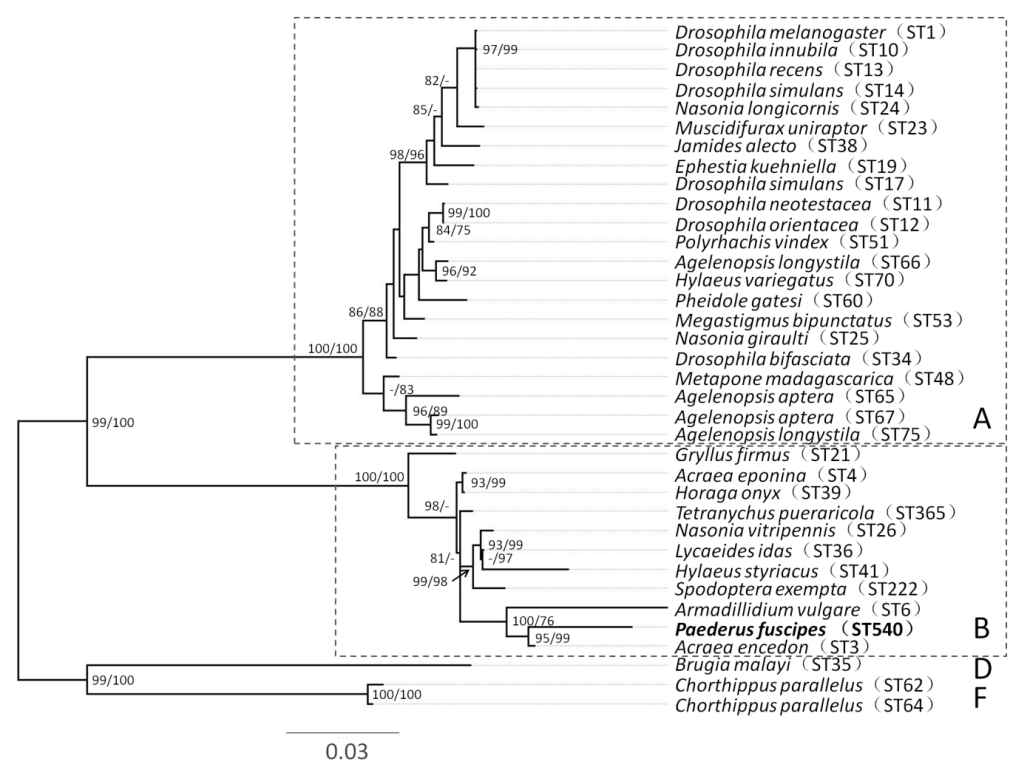

Figure 1. Maximum-likelihood phylogenetic tree of Wolbachia MLST sequences from P. fuscipes and additional ST sequences from a wide range of host species. The phylogeny is inferred by IQTREE. Numbers beside nodes are IQTREE ultrafast bootstrap and SH-aLRT values. The affiliation to the respective supergroup $(\mathbf{A}, \mathbf{B}, \mathbf{D}, \mathbf{F})$ is indicated. 
The Wolbachia infection densities analyzed through qPCR with the specific wsp gene along with an endogenous control gene (RPS3) were found to vary significantly $\left(\mathrm{F}_{(3,32)}=16.023, p<0.01\right)$ across the developmental stages. The infection density in adults was significantly higher than in any other life stage (Figure 2). Moreover, the Wolbachia infection density significantly varied between host body parts and tissues, both in females $\left(\mathrm{F}_{(4,40)}=79.783, p<0.01\right.$; Figure 3$)$ and males $\left(\mathrm{F}_{(4,40)}=68.353, p<0.01\right.$; Figure 3), with significantly high infection densities in reproductive tissues and lower densities in the gut (Figure 3). However, the relative Wolbachia densities between females and males for body parts and tissues were not significantly different. The densities of Wolbachia are therefore substantially influenced by developmental stage and tissues, but not gender.

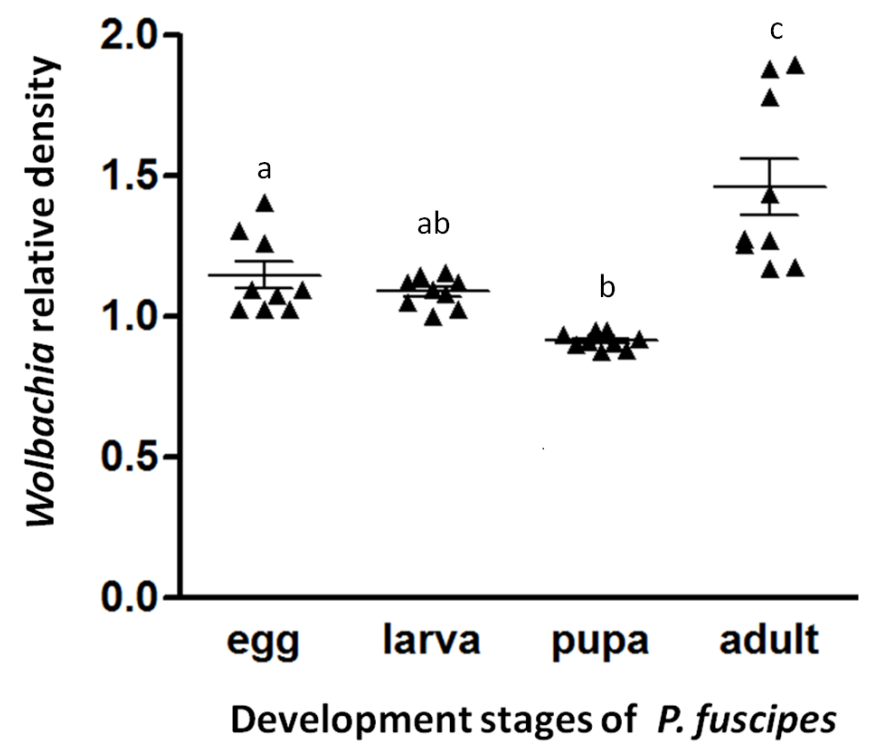

Figure 2. Relative Wolbachia density was measured across different developmental stages. Nine biological replicates were tested for each development stage. This would include both the individuals used from larvae to adults, and the egg pools. Each data point represents the average of three technical replicates. The bars represent mean \pm standard error $(n=9)$ and the different letters above the scatter dot plot indicate a significant difference between developmental stages $(p<0.05)$.

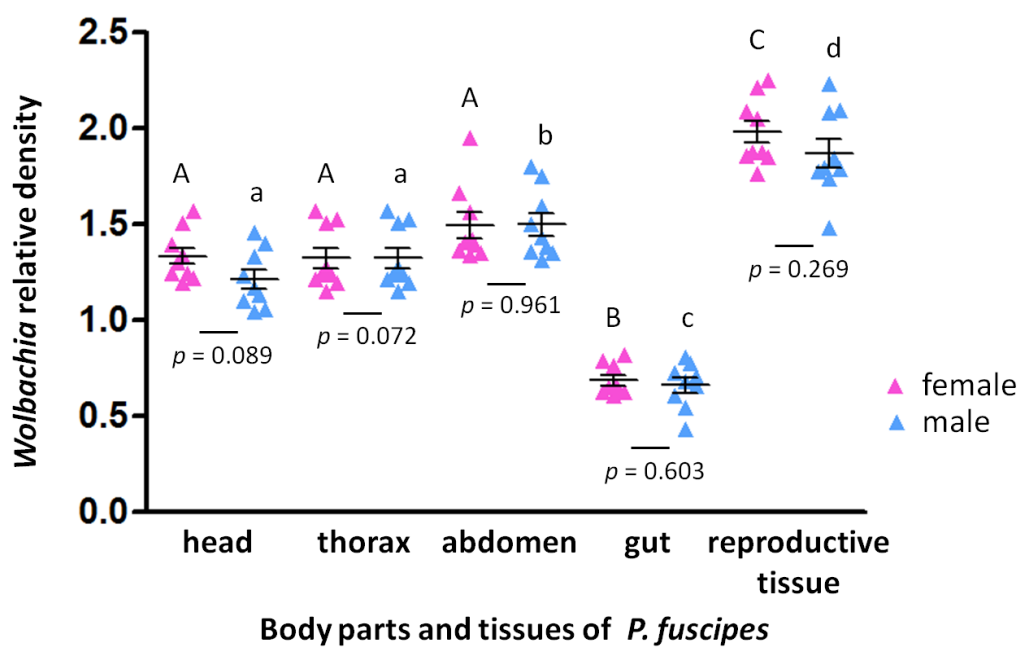

Figure 3. Relative Wolbachia density was measured across different body parts and tissues. Nine P. fuscipes were tested per treatment. Each data point represents the average of three technical replicates. The bars represent mean \pm standard error $(n=9)$ and the different letters above the scatter dot plot indicate significant difference between developmental stages $(p<0.05)$. Uppercase letters represent female while male is represented by lowercase letters. 


\section{Discussion}

Based on phylogenetic reconstructions, Wolbachia species exist in 17 supergroups designated by the letters A-R, with supergroup G being controversial [57-59]. The Wolbachia infections in Coleoptera characterized so far belong to supergroups A, B or F. In total, 12\% of Coleopteran species tested to date harbored Wolbachia from supergroup A, another 12\% harbored Wolbachia from supergroup B and only three species harbored Wolbachia from supergroup F [22]. In this study, Wolbachia infections screened from all tested samples of $P$. fuscipes were positive and belonged to supergroup B. The Wolbachia from the B supergroup in Coleoptera may affect beetle hosts in several ways. They have been shown to induce cytoplasmic incompatibility in Altica lythri from Central Europe [21], Callosobruchus chinensis from Japan [60] and Conotrachelus nenuphar from the USA [61]. Additionally, they have been suspected as inducing parthenogenesis in Aramigus conirostris from South America [62], and male killing in Adalia bipunctata from Russia [63].

We provided a quantitative analysis of Wolbachia infection densities across different development stages, body parts and tissues of $P$. fuscipes by qPCR. All individuals were Wolbachia positive, suggesting accurate Wolbachia vertical transmission by a parent to its offspring. Wolbachia density in adults was higher than in any other life stage (eggs, larvae and pupae) while the infection density in pupae was lowest (Figure 2). While there is a statistical difference, this difference may not equate to any biological differences. The Wolbachia density dynamics for the life stages in P. fuscipes were in accordance with those for three other Coleopteran species, Tribolium confusum [31], Octodonta nipae [53], and Brontispa longissima [64]. Wolbachia may be subject to the differential control of proliferation during the development of hosts [31]. The high Wolbachia density in adults and in eggs may be caused by functional associations with those host tissues. Since Wolbachia are primarily vertically transmitted from mothers to offspring through the egg cytoplasm, Wolbachia density is expected to be higher in the reproductive tissues of adults and in eggs [31,53,64]. Many studies have reported that Wolbachia display a strong tropism for the germline so as to ensure vertical transmission, particularly after rare horizontal transfer, as discussed for Drosophila [34,65,66].

Kellner and Dettner [67] noted that pederin is synthesized in about $90 \%$ of the females, and can be transferred to their offspring. The discovery of the pederin biosynthetic gene cluster led to the finding that the endosymbiotic Gram-negative bacteria, identified as closely related to Pseudomonas aeruginosa, were the producers of these compounds [68,69]. Kador et al. [41] found that Pseudomonas-like endosymbionts are located inside a structure of the female genitalia of $P$. riparius, based on FISH investigations. The Pseudomonas-like endosymbionts distributed in the female genitalia of Paederus species produce pederin as a defensive compound against insect and arachnid predators, and this does not apparently decrease the fitness of their hosts [70]. Maleki-Ravasan et al. [24] reported that the coinfection rates of both Pseudomonas-like endosymbionts and Wolbachia were $70.59 \%$ in females and $17.57 \%$ in males. Perhaps Wolbachia and Pseudomonas may interact with each other and with their Paederus beetles. It is unclear whether the Pseudomonas regulates the population of Wolbachia via pederin or not. Hence, the co-occurrence of Wolbachia and Pseudomonas in rove beetles may imply that Wolbachia is adapted to cope with adverse conditions triggered by Pseudomonas [71]. The nature of such potential interactions needs further investigation, and the effect of Wolbachia on reproduction in rove beetles also needs to be examined.

\section{Conclusions}

This study demonstrated that Wolbachia from $P$. fuscipes belonged to supergroup B, based on an analysis of MLST genotyping. The infection density in adults was higher than in any other life stage, and the reproductive tissues in adults had the highest infection densities, with similar densities between the sexes. These findings provide a starting point for understanding Wolbachia infection dynamics in $P$. fuscipes and interactions with other components of the microbiota, and could be a potential area for future research. 
Supplementary Materials: The following are available online at http://www.mdpi.com/2075-4450/11/9/625/s1, Table S1: Accession number of various host lines used in this study.

Author Contributions: Conceptualization, W.J.; methodology, C.G. and Z.Z.; analysis, J.F., S.M. and L.S.; resources, W.Y., J.Z. and J.H.; writing-original draft preparation, W.J.; writing—review and editing, A.A.H.; supervision, W.J. All authors have read and agreed to the published version of the manuscript.

Funding: This study was financially supported by grants from National Natural Science Foundation of China (No.31401997), Shanghai Natural Science Foundation (20ZR1440800) and Shanghai Municipal Human Resources and Social Security Bureau (No.2019112).

Acknowledgments: Authors are thankful to anonymous reviewers for their valuable feedback and suggestions on a previous draft of this manuscript.

Conflicts of Interest: The authors declare no conflict of interest.

\section{References}

1. Zug, R.; Hammerstein, P. Still a host of hosts for Wolbachia: Analysis of recent data suggests that $40 \%$ of terrestrial arthropod species are infected. PLoS ONE 2012, 7, e38544. [CrossRef]

2. Raychoudhury, R.; Baldo, L.; Oliveira, D.C.S.G.; Werren, J.H. Modes of acquisition of Wolbachia: Horizontal transfer, hybrid introgression, and codivergence in the Nasonia species complex. Evolution 2009, 63, 165-183. [CrossRef]

3. Yen, J.H.; Barr, A.R. New hypothesis of the cause of cytoplasmic incompatibility in Culex pipiens L. Nature 1971, 232, 657-658. [CrossRef]

4. Stouthamer, R.; Breeuwert, J.A.; Luck, R.F.; Werren, J.H. Molecular identification of microorganisms associated with parthenogenesis. Nature 1993, 361, 66-68. [CrossRef]

5. Rigaud, T.; Souty-Grosset, C.; Raimond, R.; Mocquard, J.P.; Juchault, P. Feminizing endocytobiosis in the terrestrial crustacean Armadillidium vulgare Latr. (Isopoda): Recent acquisi-tions. Endocytobiosis Cell Res. 1991, 7, 259-273.

6. Hurst, G.D.D.; Jiggins, F.M. Male-killing bacteria in insects: Mechanisms, incidence, and implications. Emerg. Infect. Dis. 2000, 6, 329-336. [CrossRef]

7. Darby, A.C.; Armstrong, S.D.; Bah, G.S.; Kaur, G.; Hughes, M.A.; Kay, S.M.; Koldkjær, P.; Rainbow, L.; Radford, A.D.; Blaxter, M.L.; et al. Analysis of gene expression from the Wolbachia genome of a filarial nematode supports both metabolic and defensive roles within the symbiosis. Genome Res. 2012, 22, 2467-2477. [CrossRef] [PubMed]

8. Dedeine, F.; Boulétreau, M.; Vavre, F. Wolbachia requirement for oogenesis: Occurrence within the genus Asobara (Hymenoptera, Braconidae) and evidence for intraspecific variation in A. tabida. Heredity 2005, 95, 394-400. [CrossRef] [PubMed]

9. Hosokawa, T.; Ryuichi, K.; Kikuchi, Y.; Meng, X.Y.; Fukatsu, T. Wolbachia as a bacteriocyte-associated nutritional mutualist. Proc. Natl. Acad. Sci. USA 2010, 107, 769-774. [CrossRef] [PubMed]

10. Kriesner, P.; Hoffmann, A.A.; Lee, S.F.; Turelli, M.; Weeks, A.R. Rapid sequential spread of two Wolbachia variants in Drosophila simulans. PLoS Pathog. 2013, 9, e1003607. [CrossRef]

11. Moreira, L.A.; Iturbe-Ormaetxe, I.; Jeffery, J.A.; Lu, G.J.; Pyke, A.T.; Hedges, L.M.; Rocha, B.C.; Hall-Mendelin, S.; Day, A.; Riegler, M.; et al. A Wolbachia symbiont in Aedes aegypti limits infection with Dengue, Chikungunya, and Plasmodium. Cell 2009, 139, 1268-1278. [CrossRef] [PubMed]

12. Hughes, G.L.; Koga, R.; Xue, P.; Fukatsu, T.; Rasgon, J.L. Wolbachia infections are virulent and inhibit the human malaria parasite Plasmodium falciparum in Anopheles gambiae. PLoS Pathog. 2011, 7, e1002043. [CrossRef] [PubMed]

13. Micieli, M.V.; Glaser, R.L. Somatic Wolbachia (Rickettsiales: Rickettsiaceae) levels in Culex quinquefasciatus and Culex pipiens (Diptera: Culicidae) and resistance to West Nile virus infection. J. Med. Entomol. 2014, 51, 189-199. [CrossRef] [PubMed]

14. Caragata, E.P.; Dutra, H.L.C.; Moreira, L.A. Exploiting intimate relationships: Controlling mosquito-transmitted disease with Wolbachia. Trends Parasitol. 2016, 32, 207-218. [CrossRef] [PubMed]

15. Flores, H.A.; O'Neill, S.L. Controlling vector-borne diseases by releasing modified mosquitoes. Nat. Rev. Microbiol. 2018, 16, 508-518. [CrossRef] 
16. Hoffmann, A.A.; Montgomery, B.L.; Popovici, J.; Iturbe-Ormaetxe, I.; Johnson, P.H.; Muzzi, F.; Greenfield, M.; Durkan, M.; Leong, Y.S.; Dong, Y. Successful establishment of Wolbachia in Aedes populations to suppress dengue transmission. Nature 2011, 476, 454-457. [CrossRef]

17. Bian, G.; Joshi, D.; Dong, Y.; Lu, P.; Zhou, G.; Pan, X.; Xu, Y.; Dimopoulos, G.; Xi, Z. Wolbachia invades Anopheles stephensi populations and induces refractoriness to Plasmodium infection. Science 2013, 340, 748-751. [CrossRef]

18. Ryan, P.A.; Turley, A.P.; Wilson, G.; Hurst, T.P.; Retzki, K.; Brown-Kenyon, J.; Hodgson, L.; Kenny, N.; Cook, H.; Montgomery, B.L. Establishment of wMel Wolbachia in Aedes aegypti mosquitoes and reduction of local dengue transmission in Cairns and surrounding locations in northern Queensland, Australia. Gates Open Res. 2019, 3, 1547. [CrossRef]

19. Nazni, W.A.; Hoffmann, A.A.; Afizah, A.N.; Cheong, Y.L.; Mancini, M.V.; Golding, N.; Kamarul, G.M.R.; Arif, M.A.K.; Thohir, H.; Syamimi, H.N. Establishment of Wolbachia strain wAlbB in Malaysian populations of Aedes aegypti for dengue control. Curr. Biol. 2019, 29, 4241-4248. [CrossRef]

20. Clark, T.L.; Meinke, L.J.; Skoda, S.R.; Foster, J.E. Occurrence of Wolbachia in selected diabroticite (Coleoptera: Chrysomelidae) beetles. Ann. Entomol. Soc. Am. 2001, 94, 877-885. [CrossRef]

21. Jäckel, R.; Mora, D.; Dobler, S. Evidence for selective sweeps by Wolbachia infections: Phylogeny of Altica leaf beetles and their reproductive parasites. Mol. Ecol. 2013, 22, 4241-4255. [CrossRef] [PubMed]

22. Kajtoch, Ł.; Kotásková, N. Current state of knowledge on Wolbachia infection among Coleoptera: A systematic review. PeerJ 2018, 6, e4471. [CrossRef]

23. Lachowska, D.; Kajtoch, Ł.; Knutelski, S. Occurrence of Wolbachia in central European weevils: Correlations with host systematics, ecology and biology. Entomol. Exp. Appl. 2010, 135, 105-118. [CrossRef]

24. Maleki-Ravasan, N.; Akhavan, N.; Raz, A.; Jafari, M.; Zakeri, S.; Djadid, N.D. Co-occurrence of pederin-producing and Wolbachia endobacteria in Paederus fuscipes Curtis, 1840 (Coleoptera: Staphilinidae) and its evolutionary consequences. MicrobiologyOpen 2018, 8, e777. [CrossRef]

25. Sontowski, R.; Bernhard, D.; Bleidorn, C.; Schlegel, M.; Gerth, M. Wolbachia distribution in selected beetle taxa characterized by PCR screens and MLST data. Ecol. Evol. 2015, 5, 4345-4353. [CrossRef]

26. Yun, Y.; Peng, Y.; Liu, F.X.; Lei, C. Wolbachia screening in spiders and assessment of horizontal transmission between predator and prey. Neotrop. Entomol. 2011, 40, 164-169.

27. Zhang, Q.; Wu, X.; Liu, Z. Primary screening of plant essential oils as insecticides, fumigants, and repellents against the health pest Paederus fuscipes (Coleoptera: Staphylinidae). J. Econ. Entomol. 2016, 109, 2388-2396. [CrossRef]

28. Frank, J.H.; Kanamitsu, K. Paederus, sensu lato (Coleoptera: Staphylinidae): Natural history and medical importance. J. Med. Entomol. 1987, 24, 155-191. [CrossRef]

29. Veraldi, S.; Cuka, E.; Chiaratti, A.; Nazzaro, G.; Gianotti, R.; Süss, L. Paederus fuscipes dermatitis: A report of nine cases observed in Italy and review of the literature. Eur. J. Dermatol. 2013, 23, 387-391. [CrossRef]

30. Schunkert, E.M.; Aschoff, N.S.; Grimmer, F.; Wiemann, C.; Zillikens, D. Paederus dermatitis-Touched by champion flies-Three clinical manifestations of pederin toxin-inflicted dermatitis. Int. J. Dermatol. 2018, 57, 989-991. [CrossRef]

31. Ming, Q.L.; Shen, J.F.; Cheng, C.; Liu, C.M.; Feng, Z.J. Wolbachia infection dynamics in Tribolium confusum (Coleoptera: Tenebrionidae) and their effects on host mating behavior and reproduction. J. Econ. Entomol. 2015, 108, 1408-1415. [CrossRef]

32. Dobson, S. Wolbachia infections are distributed throughout insect somatic and germ line tissues. Insect Biochem. Molec. 1999, 29, 153-160. [CrossRef]

33. Binnington, K.C.; Hoffmann, A.A. Wolbachia-like organisms and cytoplasmic incompatibility in Drosophila simulans. J. Invertebr. Pathol. 1989, 54, 344-352. [CrossRef]

34. Zouache, K.; Voronin, D.; Tran-Van, V. Persistent Wolbachia and cultivable bacteria infection in the reproductive and somatic tissues of the mosquito vector Aedes albopictus. PLoS ONE 2009, 4, e6388. [CrossRef]

35. Frydman, H.M.; Li, J.M.; Robson, D.N.; Wieschaus, E. Somatic stem cell niche tropism in Wolbachia. Nature 2006, 441, 509-512. [CrossRef]

36. Dittmer, J.; Beltran-bech, S.; Lesobre, J.; Raimond, M.; Johnson, M.; Bouchon, D. Host tissues as microhabitats for Wolbachia and quantitative insights into the bacterial community in terrestrial isopods. Mol. Ecol. 2014, 23, 2619-2635. [CrossRef] 
37. Espino, C.I.; Gomez, T.; Gonzalez, G. Detection of Wolbachia bacteria in multiple organs and feces of the triatomine insect Rhodnius pallescens (Hemiptera, Reduviidae). Appl. Environ. Microb. 2009, 75, 547-550. [CrossRef]

38. Ijichi, N.; Kondo, N.; Matsumoto, R. Internal spatiotemporal population dynamics of infection with three Wolbachia strains in the adzuki bean beetle, Callosobruchus chinensis (Coleoptera: Bruchidae). Appl. Environ. Microb. 2002, 68, 4074-4080. [CrossRef]

39. Kaur, R.; Martinez, J.; Rota-Stabelli, O.; Jiggins, F.M.; Miller, W.J. Age, tissue, genotype and virus infection regulate Wolbachia levels in Drosophila. Mol. Ecol. 2020, 29, 2063-2079. [CrossRef]

40. Kellner, R.L.L.; Dettner, K. Allocation of pederin during lifetime of Paederus rove beetles (Coleoptera:Staphylinidae): Evidence for polymorphism of hemolymph toxin. J. Chem. Ecol. 1995, 21, 1719-1733. [CrossRef]

41. Kador, M.; Horn, M.A.; Dettne, K. Novel oligonucleotide probes for in situ detection of pederin-producing endosymbionts of Paederus riparius rove beetles (Coleoptera: Staphylinidae). FEMS Microbiol. Lett. 2011, 319, 73-81. [CrossRef]

42. Jiang, W.B.; Zhu, J.Q.; Chen, M.H.; Yang, Q.C.; Du, X.; Chen, S.Y.; Zhang, L.N.; Yu, Y.M.; Yu, W.D. Wolbachia infection status and genetic structure in natural populations of Polytremis nascens (Lepidoptera: Hesperiidae). Infect. Genet. Evol. 2014, 27, 202-211. [CrossRef]

43. Werren, J.H.; Windsor, D.M. Wolbachia infection frequencies in insects: Evidence of a global equilibrium? Proc. Biol. Sci. 2000, 267, 1277-1285. [CrossRef]

44. Jiang, W.B.; Zhu, J.Q.; Wu, Y.J.; Li, L.Z.; Li, Y.Y.; Ge, C.; Wang, Y.; Endersby, N.M.; Hoffmann, A.A.; $\mathrm{Yu}$, W.D. Influence of Wolbachia infection on mitochondrial DNA variation in the genus Polytremis (Lepidoptera: Hesperiidae). Mol. Phylogenet. Evol. 2018, 129, 158-170. [CrossRef]

45. Baldo, L.; Lo, N.; Werren, J.H. Mosaic nature of Wolbachia surface protein. J. Bacteriol. 2005, 187, 5406-5418. [CrossRef]

46. Baldo, L.; Dunning, H.J.C.; Jolley, K.A.; Bordenstein, S.R.; Biber, S.A.; Choudhury, R.R.; Hayashi, C.; Maiden, M.C.J.; Tettelin, H.; Werren, J.H. Multilocus sequence typing system for the endosymbiont Wolbachia pipientis. Appl. Environ. Microb. 2006, 72, 7098-7110. [CrossRef]

47. Hall, T.A. BioEdit: A user-friendly biological sequence alignment editor an analysis program for Windows 95/98/NT. Nucleic Acids Symp. Ser. 1999, 41, 95-98.

48. Lanfear, R.; Calcott, B.; Ho, S.Y.; Guindon, S. Partitionfinder: Combined selection of partitioning schemes and substitution models for phylogenetic analyses. Mol. Biol. Evol. 2012, 29, 1695-1701. [CrossRef]

49. Nguyen, L.T.; Schmidt, H.A.; von Haeseler, A.; Minh, B.Q. IQ-TREE: A fast and effective stochastic algorithm for estimating maximum-likelihood phylogenies. Mol. Biol. Evol. 2015, 32, 268-274. [CrossRef]

50. Hoang, D.T.; Chernomor, O.; von Haeseler, A.; Minh, B.Q.; Vinh, L.S. UFBoot2: Improving the ultrafast bootstrap approximation. Mol. Biol. Evol. 2018, 35, 518-522. [CrossRef]

51. Minh, B.Q.; Nguyen, M.-A.T.; von Haeseler, A. Ultrafast approximation for phylogenetic bootstrap. Mol. Biol. Evol. 2013, 30, 1188-1195. [CrossRef]

52. Li, Y.Y.; Zhu, J.Q.; Ge, C.; Wang, Y.; Zhao, Z.M.; Ma, S.J.; Hoffmann, A.A.; Endersby, N.M.; Liu, Q.X.; $\mathrm{Yu}$, W.D.; et al. Molecular Phylogeny and Historical Biogeography of the Butterfly Tribe Aeromachini Tutt (Lepidoptera: Hesperiidae) from China. Cells 2019, 8, 294. [CrossRef]

53. Ali, H.; Muhammad, A.; Islam, S.U.; Islam, W.; Hou, Y.M. A novel bacterial symbiont association in the hispid beetle, Octodonta nipae (Coleoptera: Chrysomelidae), their dynamics and phylogeny. Microb. Pathog. 2018, 118, 378-386. [CrossRef]

54. Zhang, H.; Tang, B.; Lin, Y.; Chen, Z.; Zhang, X.; Ji, T.; Zhang, X.; Hou, Y. Identification of three prophenoloxidase-activating factors (PPAFs) from an invasive beetle Octodonta nipae Maulik (Coleoptera: Chrysomelidae) and their roles in the prophenoloxidase activation. Arch. Insect Biochem. Physiol. 2017, 96, e21425. [CrossRef]

55. Livak, K.J.; Schmittgen, T.D. Analysis of Relative Gene Expression Data Using Real-Time Quantitative PCR and the $2^{-\Delta \Delta C T}$ Method. Methods 2001, 25, 402-408. [CrossRef] [PubMed]

56. Jiggins, F.M. Male-killing Wolbachia and mitochondrial DNA: Selective sweeps, hybrid introgression and parasite population dynamics. Genetics 2003, 164, 5-12.

57. Augustinos, A.A.; Santos-Garcia, D.; Dionyssopoulou, E.; Moreira, M.; Papapanagiotou, A.; Scarvelakis, M.; Doudoumis, V.; Ramos, S.; Aguiar, A.F. Detection and characterization of Wolbachia infections in natural populations of Aphids: Is the hidden diversity fully unraveled? PLoS ONE 2011, 6, e28695. [CrossRef] 
58. Baldo, L.; Werren, J.H. Revisiting Wolbachia supergroup typing based on WSP: Spurious lineages and discordance with MLST. Curr. Microbiol. 2007, 55, 81-87. [CrossRef]

59. Wang, G.H.; Jia, L.Y.; Xiao, J.H.; Huang, D.W. Discovery of a new Wolbachia supergroup in cave spider species and the lateral transfer of phage WO among distant hosts. Infect. Genet. Evol. 2016, 41, 1-7. [CrossRef]

60. Kondo, N.; Ijichi, N.; Shimada, M.; Fukatsu, T. Prevailing triple infection with Wolbachia in Callosobruchus chinensis (Coleoptera: Bruchidae). Mol. Ecol. 2002, 11, 167-180. [CrossRef]

61. Zhang, X.; Luckhart, S.; Tu, Z.; Pfeiffer, D.G. Analysis of Wolbachia strains associated with Conotrachelus nenuphar (Coleoptera: Curculionidae) in the eastern United States. Environ. Entomol. 2010, 39, 396-405. [CrossRef] [PubMed]

62. Rodriguero, M.S.; Confalonieri, V.A.; Guedes, J.V.; Lanteri, A.A. Wolbachia infection in the tribe Naupactini (Coleoptera, Curculionidae): Association between thelytokous parthenogenesis and infection status. Insect Mol. Biol. 2010, 19, 631-640. [CrossRef] [PubMed]

63. Majerus, M.E.N.; Hinrich, J.; Schulenburg, G.V.D.; Zakharov, I.A. Multiple causes of male-killing in a single sample of the two-spot ladybird, Adalia bipunctata (Coleoptera: Coccinellidae) from Moscow. Heredity 2010, 84, 605-609. [CrossRef] [PubMed]

64. Ali, H.; Abrar, M.; Hou, Y. Infection density dynamics and phylogeny of Wolbachia associated with coconut hispine beetle, Brontispa longissima (Gestro) (Coleoptera: Chrysomelidae) by multilocus sequence type (MLST) genotyping. J. Microbiol. Biotechnol. 2018, 28, 796-808. [CrossRef] [PubMed]

65. Hadfield, S.J.; Axton, J.M. Germ cells colonized by endosymbiotic bacteria. Nature 1999, 402, 482. [CrossRef] [PubMed]

66. Serbus, L.R.; Sullivan, W. A cellular basis for Wolbachia recruitment to the host germline. PLoS Pathog. 2007, 3, e190. [CrossRef]

67. Pavan, M.; Bo, G. Pederin, toxic principle obtained in the crystalline state from the beetle Paederus fuscipes Curt. Physiol. Comp. Oecol. 1953, 3, 307-312.

68. Kellner, R.L.L. Suppression of pederin biosynthesis through antibiotic elimination of endosymbionts in Paederus sabaeus. J. Insect Physiol. 2001, 47, 475-483. [CrossRef]

69. Piel, J. A polyketide synthase-peptide synthetase gene cluster from an uncultured bacterial symbiont of Paederus beetles. Proc. Natl. Acad. Sci. USA 2002, 99, 14002-14007. [CrossRef]

70. Kellner, R.L.L.; Dettner, K. Differential efficacy of toxic pederin in deterring potential arthropod predators of Paederus (Coleoptera: Staphylinidae) offspring. Oecologia 1996, 107, 293-300. [CrossRef]

71. Pankewitz, F.; Zollmer, A.; Hilker, M.; Graser, Y. Presence of Wolbachia in insect eggs containing antimicrobially active anthraquinones. Microb. Ecol. 2007, 54, 713-721. [CrossRef] [PubMed] 